\title{
Identifikasi Dampak Jenis Olahraga Terhadap Kekuatan Genggaman Tangan (Studi Kasus Pada Mahasiswa Jurusan Pendidikan Olahraga UKSW)
}

\author{
Dewi Intan Purwitasari ${ }^{1, *}$, Jodelin Muninggar ${ }^{1}$, Nur Aji Wibowo ${ }^{1}$ \\ ${ }^{1}$ Jurusan Fisika, Fakultas Sains dan Matematika, Universitas Kristen Satya Wacana, Salatiga, Jawa Tengah \\ 50711 \\ *email korespondensi: dewiiiintaann@gmail.com
}

Received : 6 Agustus 2019; Revised : 24 Agustus 2019; Accepted : 17 Februari 2020; Published : 12 Maret 2020

\begin{abstract}
ABSTRAK
Identifikasi dampak dari jenis olahraga terhadap kekuatan genggam tangan telah dilakukan melalui pengukuran kekuatan genggam tangan dengan menggunakan hand-dynamometer. Identifikasi ini merupakan salah satu metode yang valid, sederhana, cepat, mudah dilakukan, tidak menimbulkan efek samping, dan dapat menggambarkan kekuatan seluruh tubuh. Kekuatan genggam tangan telah banyak digunakan sebagai parameter fungsionalitas dua puluh tujuh anggota tubuh bagian atas dan kesehatan umum. Jenis penelitian ini adalah deskriptif kuantitatif dengan sampel berjumlah 40 mahasiwa Jurusan Pendidikan Olahraga Universitas Kristen Satya Wacana (UKSW). Dari hasil pengelompokan sampel didapatkan dua kelompok bidang minat berbeda, tujuh belas mahasiswa memiliki bidang minat dalam olahraga yang banyak menggunakan tangan (basket, voli, badminton, dan tenis meja) dan dua puluh tiga mahasiswa memiliki bidang minat dalam olahraga yang banyak menggunakan kaki (sepak bola, futsal, dan marathon). Uji statistik yang digunakan adalah uji One Way Anova dan Regresi Linier dengan tingkat kebenaran 0,05. Dari uji One Way Anova didapatkan nilai signifikansi sebesar 0,000 N dan 0,000 Ns. Angka ini menunjukkan bahwa terdapat dampak yang signifikan antara jenis olahraga terhadap kekuatan genggam tangan. Dari uji Regresi Linier juga didapatkan nilai signifikansi sebesar $0,000 \mathrm{~N}$ dan $0,000 \mathrm{Ns}$ yang menunjukkan bahwa terdapat dampak dari jenis olahraga terhadap kekuatan genggam tangan.
\end{abstract}

Kata-kata kunci: ANOVA; hand-dynamometer; jenis olahraga; kekuatan genggam tangan; regresi

\section{PENDAHULUAN}

Kemampuan untuk menggenggam merupakan salah satu fungsi yang paling penting dari tangan. Kekuatan genggaman dapat digunakan untuk merefleksikan kekuatan otot secara keseluruhan. Kekuatan genggaman tangan (handgrip strength) memerlukan kombinasi aksi dari sejumlah otot tangan dan lengan bawah, dan aksi ini sangat berperan dalam aktivitas dasar sehari-hari. Sifat elastik adalah kemampuan benda untuk kembali ke bentuk awalnya segera setelah gaya luar yang diberikan benda itu dihilangkan (Souisa, 2011). Kelelahan (fatigue) didefinisikan sebagai proses perubahan struktur permanen progressive localized pada kondisi yang menghasilkan fluktuasi regangan dan tegangan dibawah kekuatan tariknya dan pada satu titik atau banyak titik yang dapat memuncak menjadi retak (crack) atau patahan (fracture) secara keseluruhan sesudah fluktuasi tertentu. Kelelahan dapat menghasilkan keadaan yang berbedabeda, tetapi semuanya berakibat pada pengurangan kapasitas kerja dan ketahanan tubuh (Jakobsen, Rask, \& Kondrup, 2010). Salah satu cara untuk mengetahui kekuatan otot adalah dengan melakukan uji kekuatan genggam tangan, yaitu tes kekuatan maksimal yang dihalkan oleh otot. Pada orang sehat, usia dan jenis kelamin adalah faktor terkuat yang mempengaruhi kekuatan genggaman tangan (Jakobsen dkk., 2010). Kekuatan genggam tangan telah banyak digunakan sebagai parameter fungsionalitas dua puluh tujuh anggota tubuh bagian atas dan kesehatan umum (Lopes dkk., 2018).

Informasi mengenai kekuatan genggam tangan sangat penting karena dapat memprediksi kemampuan otot atau kemampuan fisik dalam beraktivitas dan juga untuk mendiagnosa cacat terutama yang berkaitan dengan otot tangan sehingga dapat merencanakan pencegahan (Koley \& Singh, 2010; Teimoory, Nasiri, Khodamoradi, \& Ebrahimi, 2011). Kekuatan otot merupakan salah satu variabel penting dalam pemeriksaan dan evaluasi kebugaran fisik. Olahraga merupakan suatu kegiatan jasmani yang dilakukan dengan maksud untuk memelihara kesehatan dan memperkuat otot-otot tubuh. Dengan melakukan aktivitas fisik yang rutin yaitu olahraga mampu meningkatkan kekuatan otot. Keaktifan melakukan aktivitas fisik salah satunya olahraga mampu memengaruhi kekuatan otot (Hermawan \& 
Soegiyanto -, 2015). Selama ini belum ada data tentang dampak jenis olahraga terhadap kekuatan genggam tangan dan ketahanan otot mahasiswa Pendidikan Olahraga di Universitas Kristen Satya Wacana (UKSW). Oleh karena itu, penelitian ini dilakukan untuk mengidentifikasi dampak dari jenis olahraga terhadap kekuatan dan ketahanan otot tangan di lingkungan mahasiswa. Penelitian ini diharapkan dapat bermanfaat untuk memberikan informasi untuk keperluan data klinis tentang kekuatan maksimal dan ketahanan otot tangan.

\section{EKSPERIMEN}

\section{Prosedur Kerja}

Di dalam penelitian ini, pengambilan data kekuatan genggam tangan dilakukan terhadap mahasiswa Jurusan Pendidikan Olahraga di Universitas Kristen Satya Wacana (UKSW). Untuk menentukan kriteria sampel digunakan teknik Sampling Sistematis. Tabel Isaac-Michael digunakan untuk menentukan jumlah sampel dari populasi mahasiswa jurusan Pendidikan Olahraga di UKSW dengan taraf kesalahan $5 \%$. Pengambilan data kekuatan genggam tangan dilakukan dengan menggunakan Vernier Hand Dynamometer yang tersambung dengan laptop dan logger lite dengan posisi sampel duduk dan siku ditekuk 90 derajat. Hand Dynamometer yang memiliki akurasi $\pm 0,6 \mathrm{~N}$ dan dapat mendeteksi gaya dalam tentang $0-600 \mathrm{~N}$ ini merupakan pengukur-regangan berbasis sensor gaya isometrik. Sensor ini menguatkan gaya yang diterapkan untuk mengubahnya menjadi tegangan yang dimonitor oleh lab interface dan membaca dalam satuan gaya dalam Newton $(\mathrm{N})$, pounds $(\mathrm{lb})$, atau kilogram $(\mathrm{kg})$. Pada saat pengambilan data, sampel diinstruksikan untuk menggenggam sekuat-kuatnya hand-dynamometer selama 60 detik dengan tangan kanan (tangan dominan). Besarnya impuls dapat dinyatakan dengan menghitung luasan daerah di bawah kurva $F-t$ yang ditunjukkan oleh Gambar 1 . Nilai $F_{\max }$ menunjukkan beban maksimal yang bisa ditopang oleh sampel. Besarnya $F_{\max }$ ini sebanding dengan kekuatan otot. Sedangkan luas di bawah kurva merupakan impuls yang besarnya sebanding dengan ketahanan otot.

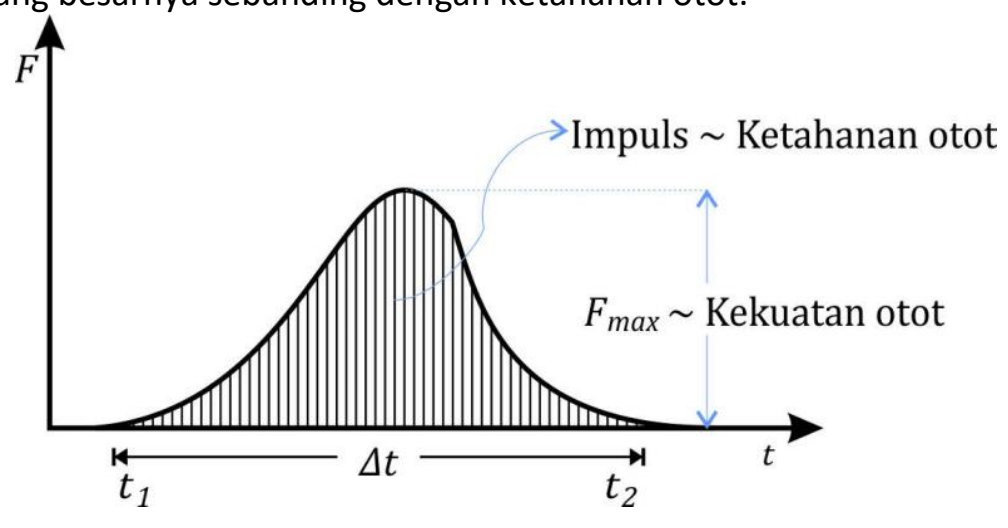

Gambar 1. Besarnya impuls ditunjukkan oleh luasan daerah di bawah kurva.

Setelah data didapat, maka dilakukan uji normalitas yang berfungsi untuk melihat apakah data sampel yang kita ambil atau kita gunakan telah mengikuti atau mendekati distribusi normal (Awang, Pattiserlihun, \& Wibowo, 2017). Selanjutnya, dilakukan uji validitas menggunakan One Way Anova yang berfungsi untuk menguji kemampuan generalisasi artinya apakah data sampel dianggap dapat mewakili populasi atau tidak (Awang dkk., 2017). Untuk pengujian persyaratan Anova digunakan perangkat lunak SPSS. Uji normalitas dilakukan dengan menggunakan uji Kolmogorov-Smirnov dan Shapiro-Wilk, karena data < 50 (Mohd Razali \& Yap, 2011). Selanjutnya, dilakukan regresi linear untuk menguji hipotesis dalam penelitian ini. Secara ringkas tahapan dalam pelaksanaan penelitian ini dapat dijelaskan dalam diagram alir yang ditunjukkan oleh Gambar 2. 


\section{Pengambilan Data}

Pengambilan data kekuatan genggam tangan pasien dilakukan dengan menggunakan Vernier Hand Dynamometer yang tersambung dengan komputer dan logger lite

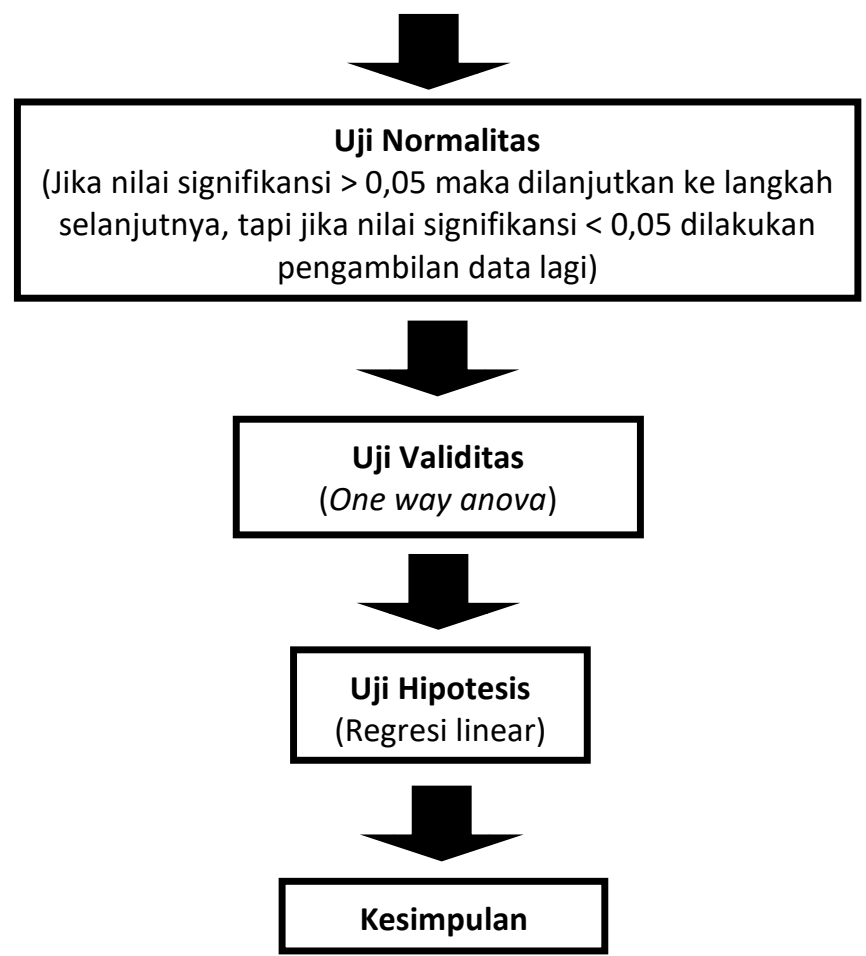

Gambar 2. Tahapan Pelaksanaan Penelitian.

\section{HASIL DAN DISKUSI}

Dalam penelitian ini digunakan dua jenis analisis dalam pemecahan hipotesis, yaitu uji One Way Anova dan uji Regresi Linier. Dalam melakukan uji One Way Anova, perlu dilakukan uji normalitas dan uji homogenitas. Uji normalitas merupakan salah satu uji mendasar yang dilakukan sebelum melakukan analisa data lebih lanjut. Uji normalitas berfungsi untuk melihat apakah data sampel yang kita ambil atau kita gunakan telah mengikuti atau mendekati distribusi normal. Uji homogenitas dilakukan untuk mengetahui apakah data homogen atau memiliki kelompok yang sejenis (Murdiyanti, Muninggar, \& Wibowo, 2018).

\section{A. Uji One Way Anova}

Tabel 1. Uji Normalitas One Way Anova

\begin{tabular}{|c|c|c|c|c|c|c|c|}
\hline & \multirow[t]{2}{*}{ Jenis Olahraga } & \multicolumn{3}{|c|}{ Kolmogorov-Smirnov ${ }^{a}$} & \multicolumn{3}{|c|}{ Shapiro-Wilk } \\
\hline & & Statistic & df & Sig. & Statistic & df & Sig. \\
\hline \multirow[t]{2}{*}{$\begin{array}{l}\text { Ketahanan } \\
\text { Otot } \\
\text { (Newton } \\
\text { detik) }\end{array}$} & $\begin{array}{c}\text { Olahraga yang banyak } \\
\text { menggunakan tangan } \\
\text { (basket, voli, bulu tangkis, } \\
\text { dan tenis meja) }\end{array}$ & 0,175 & 17 & 0,178 & 0,926 & 17 & 0,188 \\
\hline & $\begin{array}{c}\text { Olahraga yang banyak } \\
\text { menggunakan kaki (sepak } \\
\text { bola, futsal, dan } \\
\text { marathon) }\end{array}$ & 0,120 & 23 & 0,200 & 0,962 & 23 & 0,513 \\
\hline \multirow[t]{2}{*}{$\begin{array}{l}\text { Kekuatan } \\
\text { Maksimal } \\
\text { (Newton) }\end{array}$} & $\begin{array}{c}\text { Olahraga yang banyak } \\
\text { menggunakan tangan } \\
\text { (basket, voli, bulu tangkis, } \\
\text { dan tenis meja) }\end{array}$ & 0,151 & 17 & 0,200 & 0,910 & 17 & 0,101 \\
\hline & $\begin{array}{c}\text { Olahraga yang banyak } \\
\text { menggunakan kaki (sepak } \\
\text { bola, futsal, dan } \\
\text { marathon) }\end{array}$ & 0,144 & 23 & 0,200 & 0,943 & 23 & 0,204 \\
\hline
\end{tabular}


Tabel 2. Uji Homogenitas

\begin{tabular}{lcccc}
\hline & Levene Statistic & df1 & df2 & Sig. \\
\hline Ketahanan Otot (Newton detik) & 1,112 & 1 & 38 & 0,298 \\
Kekuatan maksimal (Newton) & 1,668 & 1 & 38 & 0,204 \\
\hline
\end{tabular}

Hasil uji normalitas dan uji homogenitas disajikan dalam Tabel 1 dan Tabel 2. Pengambilan keputusan dari uji normalitas dilihat dari nilai yang diperoleh pada kolom Sig. Nilai yang harus dipenuhi adalah > 0,05 agar data berdistribusi normal dan memiliki kelompok yang sejenis (Sari, Sukestiyarno, \& Agoestanto, 2017). Nilai signifikansi yang didapat dari uji normalitas berdasarkan jenis olahraga yang banyak menggunakan tangan terhadap variabel kekuatan maksimal dan ketahanan otot adalah 0,188 $\mathrm{N}$ dan 0,513 Ns. Sedangkan nilai signifikansi yang didapat dari uji normalitas berdasarkan jenis olahraga yang banyak menggunakan kaki terhadap variabel kekuatan maksimal dan ketahanan otot adalah 0,101 $\mathrm{N}$ dan 0,204 Ns. Kedua nilai tersebut lebih besar dari 0,05 $(p>0,05)$ sehingga dapat disimpulkan bahwa data tersebut berdistribusi normal dan memiliki kelompok yang sejenis. Dapat dilihat pula bahwa hasil output dari uji homogenitas memiliki nilai signifikansi sebesar 0,298 $\mathrm{N}$ dan 0,204 $\mathrm{Ns}$ atau $>0,05$. Berdasarkan data tersebut dapat diasumsikan bahwa data tersebut bersifat homogen (Sari dkk., 2017). Dari hasil uji normalitas dan uji homogenitas, syarat karakteristik data telah terpenuhi sehingga dapat dilanjutkan ke tahapan pengujian hipotesis menggunakan One Way Anova.

Tabel 3. Deskripsi Hasil Statistik

\begin{tabular}{|c|c|c|c|c|c|c|c|c|c|}
\hline & & & & \multicolumn{6}{|c|}{$\begin{array}{l}\text { 95\% Confidence } \\
\text { Interval for Mean }\end{array}$} \\
\hline & & $N$ & Mean & $\begin{array}{c}\text { Std. } \\
\text { Deviatio } \\
n\end{array}$ & $\begin{array}{l}\text { Std. } \\
\text { Error }\end{array}$ & $\begin{array}{l}\text { Lower } \\
\text { Bound }\end{array}$ & $\begin{array}{l}\text { Upper } \\
\text { Bound }\end{array}$ & $\begin{array}{c}\text { Minimu } \\
m\end{array}$ & $\begin{array}{c}\text { Maximu } \\
m\end{array}$ \\
\hline \multirow[t]{3}{*}{$\begin{array}{l}\text { Ketahanan } \\
\text { Otot } \\
\text { (Newton } \\
\text { detik) }\end{array}$} & $\begin{array}{l}\text { Olahraga yang } \\
\text { banyak } \\
\text { menggunakan } \\
\text { tangan (basket, } \\
\text { voli, bulu tangkis, } \\
\text { dan tenis meja) } \\
\end{array}$ & 17 & 9586,94 & 1474,308 & 357,572 & 8828,92 & 10344,96 & 7140 & 12540 \\
\hline & $\begin{array}{l}\text { Olahraga yang } \\
\text { banyak } \\
\text { menggunakan kaki } \\
\text { (sepak bola, futsal, } \\
\text { dan marathon) }\end{array}$ & 23 & 6475,96 & 1137,607 & 237,207 & 5984,02 & 6967,89 & 4040 & 8418 \\
\hline & Total & 40 & 7798,12 & 2011,845 & 318,101 & 7154,71 & 8441,54 & 4040 & 12540 \\
\hline \multirow[t]{3}{*}{$\begin{array}{l}\text { Kekuatan } \\
\text { Maksimal } \\
\text { (Newton) }\end{array}$} & $\begin{array}{l}\text { Olahraga yang } \\
\text { banyak } \\
\text { menggunakan } \\
\text { tangan (basket, } \\
\text { voli, bulu tangkis, } \\
\text { dan tenis meja) }\end{array}$ & 17 & 256,000 & 43,2839 & 10,4979 & 233,745 & 278,255 & 194,5 & 318,0 \\
\hline & $\begin{array}{l}\text { Olahraga yang } \\
\text { banyak } \\
\text { menggunakan kaki } \\
\text { (sepak bola, futsal, } \\
\text { dan marathon) }\end{array}$ & 23 & 183,730 & 38,4620 & 8,0199 & 167,098 & 200,363 & 110,4 & 242,5 \\
\hline & Total & 40 & 214,445 & 53,9646 & 8,5325 & 197,186 & 231,704 & 110,4 & 318,0 \\
\hline
\end{tabular}

Deskripsi hasil uji One Way Anova disajikan di dalam Tabel 3. Hipotesis dalam analisis ini adalah jenis olahraga berdampak pada kekuatan maksimal dan ketahanan otot. Kelayakan dan pemilihan variabel tersebut dapat dilihat dari nilai Standard Error (SE) dan Standard Deviation (SD). Terlihat bahwa nilai Standard Error pada setiap variabel lebih kecil dari nilai Standard Deviation setiap variabel (SE<SD). Hasil tersebut menunjukkan bahwa variabel yang digunakan dalam penelitian layak untuk dianalisis. Diperoleh juga bahwa nilai rata-rata (mean) berbeda untuk di setiap variabel terikat. Dari kategori kekuatan maksimal, dapat dilihat kedua variabel tersebut memiliki nilai rata-rata yang berbeda. Nilai rata-rata kekuatan untuk variabel olahraga yang banyak menggunakan tangan sebesar 256,00 N, dan nilai rata-rata untuk variabel olahraga yang banyak menggunakan kaki sebesar $183,73 \mathrm{~N}$, sedangkan untuk total memiliki 
nilai rata-rata sebesar $214,44 \mathrm{~N}$. Dari kategori ketahanan otot, dan olahraga yang banyak menggunakan tangan memiliki nilai rata-rata sebesar $9.586,94 \mathrm{Ns}$, olahraga yang banyak menggunakan kaki memiliki nilai rata-rata sebesar $6.475,96 \mathrm{Ns}$, sedangkan nilai rata-rata untuk total sebesar 7.798,12 Ns.

Tabel 4. Hasil Uji One Way Anova

\begin{tabular}{ccccccc}
\hline & & $\begin{array}{c}\text { Sum of } \\
\text { Squares }\end{array}$ & $\boldsymbol{d f}$ & $\begin{array}{c}\text { Mean } \\
\text { Square }\end{array}$ & F (Newton) & Sig. \\
\hline $\begin{array}{c}\text { Ketahanan } \\
\text { Otot }\end{array}$ & $\begin{array}{c}\text { Between groups } \\
\text { (Newton }\end{array}$ & $9,460 \mathrm{E} 7$ & 1 & $9,460 \mathrm{E} 7$ & 56,839 & 0,000 \\
\cline { 2 - 7 } detik) & Wothin groups & $6,325 \mathrm{E} 7$ & 38 & 1664437,576 & & \\
\hline Kekuatan & Between groups & 51053,750 & 1 & 51053,750 & 31,030 & 0,000 \\
$\begin{array}{c}\text { Maksimal } \\
\text { (Newton) }\end{array}$ & Within groups & 62521,069 & 38 & 1645,291 & & \\
\cline { 2 - 7 } & Total & 113574,819 & 39 & & & \\
\hline
\end{tabular}

Tabel 4 menunjukkan hasil uji One Way Anova. Dari uji tersebut diperoleh nilai signifikansi pada variabel kekuatan maksimal dan ketahanan otot sebesar $0,000 \mathrm{~N}$ dan $0,000 \mathrm{Ns}$, artinya nilai signifikansi dari kedua variabel tersebut $<0,05$. Hal ini menunjukkan bahwa adanya perbedaan rata-rata yang signifikan antara kekuatan maksimal dan ketahanan otot pada mahasiswa jurusan Pendidikan Olahraga.

\section{B. Uji Regresi Linier}

Sebelum melakukan uji Regresi Linier, dilakukan uji normalitas terlebih dahulu untuk mengetahui data tersebut berdistribusi normal atau tidak. Uji normalitas dilakukan menggunakan teknik perhitungan Kolmogorov-Smirnov. Pengambilan keputusan dari uji normalitas dilihat dari nilai yang diperoleh pada baris Asymp. Sig. (2-tailed). Suatu data dikatakan berdistribusi normal apabila nilai signifikansi lebih besar dari 0,05 .

Tabel 5. Uji Normalitas Regresi Linier

\begin{tabular}{lll}
\hline & & Unstandardized Residual \\
\hline $\boldsymbol{N}$ & & 40 \\
\hline Normal Parameters $^{a}$ & Mean & $0 \mathrm{E}-7$ \\
& Std. Deviation & 0,31682661 \\
\hline Most Extreme Differences & Absolute & 0,132 \\
\hline & Positive & 0,086 \\
& Negative & $-0,132$ \\
\hline Kolmogorov-Smirnov $\boldsymbol{Z}$ & & 0,834 \\
Asymp. Sig. (2-tailed) & 0,490 \\
\hline
\end{tabular}

Berdasarkan Tabel 5, dapat dilihat nilai signifikansinya adalah 0,490. Hal ini menunjukkan bahwa data berdistribusi normal dan dalam kelompok yang sejenis sehingga dapat dilanjutkan ke tahap pengujian berikutnya.

Tabel 6. Koefisien Korelasi

\begin{tabular}{cccccc}
\hline & Model & $\boldsymbol{R}$ & $\boldsymbol{R}$ Square & $\begin{array}{c}\text { Adjusted } \boldsymbol{R} \\
\text { Square }\end{array}$ & $\begin{array}{c}\text { Std. Error of the } \\
\text { Estimate }\end{array}$ \\
\hline Kekuatan Maksimal & 1 & $0,670^{\mathrm{a}}$ & 0,450 & 0,435 & 40,56219 \\
\hline Ketahanan Otot & 1 & $0,774^{\mathrm{a}}$ & 0,599 & 0,589 & 1290,13084 \\
\hline
\end{tabular}

Berdasarkan Tabel 6 terdapat nilai R yang menunjukkan nilai koefisien korelasi. Nilai korelasi yang diperoleh adalah 0,670 dan 0,774. Berdasarkan hal tersebut, dapat diinterpretasikan bahwa hubungan antara jenis olahraga dan kekuatan maksimal serta jenis olahraga dan ketahanan otot kuat. Persentase dampak dari jenis olahraga terhadap kekuatan maksimal dan ketahanan otot dapat dilihat dari nilai $R$ Square. Nilai $R$ Square menunjukkan nilai 0,450 dan 0,599, yang artinya jenis olahraga berdampak terhadap kekuatan maksimal dan ketahanan otot sebesar $45 \%$ dan $59 \%$.

Tabel 7. Linieritas Koefisien Korelasi

\begin{tabular}{|c|c|c|c|c|c|c|c|}
\hline & Model & & Sum of Square & $d f$ & Mean Square & $F$ (Newton) & Sig. \\
\hline \multirow{3}{*}{$\begin{array}{l}\text { Kekuatan } \\
\text { Maksimal }\end{array}$} & \multirow{3}{*}{1} & Regression & 51053,750 & 1 & 51053,750 & 31,030 & $0,000^{a}$ \\
\hline & & Residual & 62521,069 & 38 & 1645,291 & & \\
\hline & & Total & 113574,819 & 39 & & & \\
\hline \multirow{3}{*}{$\begin{array}{c}\text { Ketahanan } \\
\text { Otot }\end{array}$} & \multirow{3}{*}{1} & Regression & $9,460 \mathrm{E} 7$ & 1 & $9,460 \mathrm{E} 7$ & 56,389 & $0,000^{a}$ \\
\hline & & Residual & $6,325 \mathrm{E} 7$ & 38 & 1664437,576 & & \\
\hline & & Total & $1,579 \mathrm{E} 8$ & 39 & & & \\
\hline
\end{tabular}


Penentuan taraf signifikansi atau linieritas dari Regresi dapat dilihat pada Tabel 7. Suatu data dikatakan linier jika nilai signifikansi lebih kecil dari 0,05 (Sugiyono, 2006). Linieritas dampak dari jenis olahraga terhadap kekuatan maksimal dan ketahanan otot dapat dilihat berdasarkan nilai signifikansinya. Dari hasil analisis diperoleh nilai signifikansi sebesar 0,000 atau $<0,05$, artinya data berkorelasi secara linier.

Tabel 8. Hubungan Antara Variabel $X$ (Jenis Olahraga) dengan Variabel $Y_{1}$ (Kekuatan Maksimal) dan $Y_{2}$ (Ketahanan Otot)

\begin{tabular}{|c|c|c|c|c|c|c|c|}
\hline & \multirow[b]{2}{*}{ Model } & & \multicolumn{2}{|c|}{$\begin{array}{l}\text { Unstandarized } \\
\text { Coefficients }\end{array}$} & \multirow{2}{*}{$\begin{array}{c}\begin{array}{c}\text { Standarized } \\
\text { Coefficients }\end{array} \\
\text { Beta }\end{array}$} & \multirow[b]{2}{*}{$\mathbf{t}$} & \multirow[b]{2}{*}{ Sig. } \\
\hline & & & B & Std. Error & & & \\
\hline & & (Constant) & 328,270 & 21,416 & & 15,328 & 0,000 \\
\hline $\begin{array}{l}\text { Kekuatan Maksımal } \\
\qquad\left(Y_{1}\right)\end{array}$ & 1 & $\begin{array}{l}\text { Jenis olahraga } \\
\qquad(\mathrm{X})\end{array}$ & $-72,270$ & 12,974 & $-0,670$ & $-5,570$ & 0,000 \\
\hline $\begin{array}{c}\text { Ketahanan Otot } \\
\left(Y_{2}\right)\end{array}$ & 1 & $\begin{array}{c}\text { (Constant) } \\
\text { Jenis olahraga } \\
(\mathrm{X})\end{array}$ & $\begin{array}{l}12697,926 \\
-3110,985\end{array}$ & $\begin{array}{l}681,175 \\
412,644\end{array}$ & $-0,774$ & $\begin{array}{l}18,641 \\
-7,539\end{array}$ & $\begin{array}{l}0,000 \\
0,000\end{array}$ \\
\hline
\end{tabular}

Berdasarkan Tabel 6 dan Tabel 8 diketahui bahwa korelasi antara jenis olahraga terhadap kekuatan maksimal dan ketahanan otot bersifat signifikan dan memiliki kekuatan korelasi yang ditunjukkan oleh $\alpha$ dan $R$ yang secara berturut-turut bernilai $(\alpha=0,000 \mathrm{~N} ; R=0,670)$ dan $(\alpha=0,000 \mathrm{Ns} ; R=0,774)$. Hal ini menunjukkan bahwa hipotesis dari penelitian ini diterima, atau terdapat dampak dari jenis olahraga terhadap kekuatan genggam tangan dan ketahanan otot.

Berdasarkan penelitian yang telah dilakukan, diketahui bahwa jenis olahraga mempunyai dampak terhadap kekuatan genggam otot. Olahraga yang banyak menggunakan tangan mempunyai kekuatan maksimal dan ketahanan otot yang lebih besar dibandingkan dengan olahraga yang banyak menggunakan kaki. Otot yang kuat dapat melindungi persendian yang dikelilinginya dan mengurangi kemungkinan terjadinya cedera karena aktivitas fisik. Hal ini sesuai dengan pernyataan Webber \& Porter yang menyebutkan dalam jurnalnya bahwa kekuatan otot lebih penting untuk menunjang aktivitas fisik sebagai fungsi tubuh (Webber \& Porter, 2010).

\section{KESIMPULAN}

Telah dilakukan penelitian mengenai dampak dari jenis olahraga terhadap kekuatan maksimal dan ketahanan otot. Berdasarkan hasil penelitian, dari uji One Way Anova menunjukkan bahwa terdapat pengaruh yang signifikan antara jenis olahraga terhadap kekuatan genggam tangan. Dari uji Regresi Linier diperoleh nilai signifikansi dari kekuatan maksimal dan ketahanan otot berturut-turut adalah 0,000 $\mathrm{N}$ dan 0,000 Ns. Angka-angka ini menunjukkan bahwa terdapat pengaruh dari jenis olahraga terhadap kekuatan maksimal dan ketahanan otot. Orang yang berolahraga dengan banyak aktivitas tangan mempunyai kekuatan maksimal dan ketahanan otot yang lebih besar dibandingkan orang yang berolahraga dengan banyak menggunakan kaki. Penelitian ini berguna sebagai data klinis bagi atlet untuk bisa mengetahui kondisi fisik atlet dan kekuatan genggam tangan yang bisa mengindikasikan kemungkinan cidera bagi atlet. Penelitian lebih lanjut juga dapat dilakukan karena masih terdapat kelemahan dalam penelitian ini, yaitu kurang spesifiknya jenis olahraga dalam penelitian ini.

\section{DAFTAR PUSTAKA}

Awang, J. K., Pattiserlihun, A., \& Wibowo, N. A. (2017). Pengaruh Profesi Pekerjaan Terhadap Kekuatan dan Daya Tahan Otot Tangan di Kecamatan Sidorejo, Salatiga. Dipresentasikan pada LONTAR PYSICS FORUM 2017.2 Diambil dari http://prosiding.upgris.ac.id/index.php/LPF2017/lpf17/paper/view/1721

Hermawan, A. D., \& Soegiyanto -. (2015). Pengembangan Kartu Permainan Edukatif Untuk Pengetahuan Cabang-Cabang Olahraga. Journal of Sport Sciences and Fitness, 4(2). Diambil dari https://journal.unnes.ac.id/sju/index.php/jssf/article/view/6289 
Jakobsen, L. H., Rask, I. K., \& Kondrup, J. (2010). Validation of Handgrip Strength and Endurance as a Measure of Physical Function and Quality of Life in Healthy Subjects and Patients. Nutrition (Burbank, Los Angeles County, Calif.), 26(5), 542-550. https://doi.org/10.1016/j.nut.2009.06.015

Koley, S., \& Singh, A. (2010). Effect of Hand Dominance in Grip Strength in Collegiate Population of Amritsar, Punjab, India. https://doi.org/10.1080/09720073.2010.11891125

Lopes, J., Grams, S. T., da Silva, E. F., de Medeiros, L. A., de Brito, C. M. M., \& Yamaguti, W. P. (2018). Reference Equations for Handgrip Strength: Normative Values in Young Adult and Middle-Aged Subjects. Clinical Nutrition (Edinburgh, Scotland), 37(3), 914-918. https://doi.org/10.1016/j.clnu.2017.03.018

Mohd Razali, N., \& Yap, B. (2011). Power Comparisons of Shapiro-Wilk, Kolmogorov-Smirnov, Lilliefors and Anderson-Darling Tests. J. Stat. Model. Analytics, 2.

Murdiyanti, A.N.A., Muninggar, J., \& Wibowo, N. (2018). Identifikasi Dampak Dari Jenis dan Lama Terapi Terhadap Kinerja Fungsional Tubuh Pada Pasien Kanker dengan Hand-dynamometer. Jurnal Sains dan Edukasi Sains, 1, 25-32. https://doi.org/10.24246/juses.v1i2p25-32

Sari, A. Q., Sukestiyarno, Y. L., \& Agoestanto, A. (2017). Batasan Prasyarat Uji Normalitas dan Uji Homogenitas Pada Model Regresi Linear. Unnes Journal of Mathematics, 6(2), 168-177. https://doi.org/10.15294/ujm.v6i2.11887

Souisa, M. (2011). Analisis Modulus Elastisitas dan Angka Poisson Bahan Dengan Uji Tarik. Jurnal Barekeng, $5(2), 9-14$.

Sugiyono. (2006). Statistik Untuk Penelitian. CV ALFABETA Bandung.

Teimoory, A., Nasiri, M., Khodamoradi, A., \& Ebrahimi, K. (2011). The Effects of Aging on Hand Grip Strength in The Adult Iranian Population. Australian Journal of Basic and Applied Sciences, 5, 970-973.

Webber, S. C., \& Porter, M. M. (2010). Reliability of Ankle Isometric, Isotonic, and Isokinetic Strength and Power Testing in Older Women. Physical Therapy, 90(8), 1165-1175. https://doi.org/10.2522/ptj.20090394 